\title{
ASSESSMENT OF MORING OLEIFERA LEAVES AS NATURAL SOURCE TO PRODUCE HYPOLIPIDEMIC AND ANTIOXIDATIVE FUNCTIONAL FOOD
}

\author{
Safaa A salem ${ }^{1 凶}$, El- Hofi M.A., ${ }^{2}$ Abdel latif Anaam K. ${ }^{3}$ \\ ${ }^{1,3}$ Department of Medicinal Food, National Organization for Drug Control and Research (NODCAR), 6-7, Abu- \\ Hazem Street, Pyramids Ave, 12553 Giza, Egypt. ${ }^{2}$ Food Science Dept., Fac. of Agric., Ain Shams Univ., P.O. \\ Box 68,HadayekShobra 11241, Cairo, Egypt. \\ safyahmed211@yhoo.com. \\ https://doi.org/10.34302/crpjfst/2021.13.3.5 \\ Article history: \\ Received: \\ 22 June 2021 \\ Accepted: \\ 25 August 2021 \\ Keywords: \\ Moringa oleifera leaves; \\ Antioxidant Activity; \\ Lipid Profile; \\ Rheological Properties; \\ Sensory Evaluation.

\begin{abstract}
The objectives of this work is to investigate the antioxidative and hypolipidemic effect of Moringa oleifera leaf powder(MOLP). For this purpose 36 Male rats were assigned into six groups, each of six rats; negative control group feeding with basal diet, positive control group feeding with high cholesterol diet (HCD) and three tested groups fed on $\mathrm{HCD}$ and different ratios of MOLP; 25,50 or $75 \mathrm{~g} / \mathrm{kg}$ diet, in addition to initial group, the feeding period was 45 days.

At the end of feeding period, compared to the positive control group, all tested groups demonstrated decrease in body weight. Also, as compared to the positive control, significant decreases in serum biological parameters were found, including; glucose, total lipids, triglycerides , total cholesterol, and LDL- cholesterol. Moreover increase was found in HDL-cholesterol and decrease in cholesterol and triglycerides in liver, compared to positive control group. Changes in all above parameters were according to the ratio of MOLP, each of the above three ratios with wheat flour was used to produce crackers. The dough of each product was submitted to rheological measurements using farinograph and extensograph. The best results for the rheological parameters, including; water absorption, stability time, dough development time, degree of softening and elasticity were found in dough containing $25 \%$ MOLP. The best dough was used to manufacture hypolipidemic and antioxidant crackers as functional food.
\end{abstract}

\section{Introduction}

Diet plays on important role in decreasing of atherosclerosis and coronary heart diseases, which considered the major health problem in all the world. Dietary composition plays a role in disordered lipid and lipoprotein metabolism which led to hyperlipidemia and hyperlipoproteinemia, that considered important factors in developing of coronary heart diseases. Herbal medicine contains natural substances which are important to promote health and decrease illness, it helps in decreasing lipid and cholesterol in blood (Alattar, 2006). Moringa oleifera lam is an Indian tree belongs to genus family moringacease, it was used by Greeks , Roman and anciente Egyptians (Paikraet al., 2017). $M$.oleifera contains;carotenoids, minerals, vitamins, amino acids, sterols, glycosides and phenols, also the leaves are source of protein, vitamin $\mathrm{C}$, B. carotene iron and potassium (Joshi and Mehta, 2010; 
Rajanandh et al.,2012). Moreover the plant contains different phytochemicals including; saponins, steroids, tannins, flavonoids and alkaloids (Shousha et al., 2019)., The plant can be used as fresh, cooked, or dried and powdered. The leaves are used as hypoglycemic and hypocholesterolemic agent. ( Ghasi et al., 2000 and Leone et al., 2015). The administration of M. oleifera's crude extract of leaves reduced cholesterol levels. In serum, liver, and kidney in the rats feeding with a high-fat diet (Ghasi et al., 2000; Vagelas and Sugar 2020). The leaves extract of M.oleifera inhibit high antioxidant activity, total phenolic and flavonoids. Using synthetic antioxidants in food products is not popular anymore because of their instability and also due to suspended action as promoters of carcinogenesis, therefore, there is interest in the studies of natural, nontoxic and healthy antioxidants (Tomaino et al., 2005). In the light of the above data, the objectives of the present study was to evaluate the effect of the leaves powder of $M$. oleifera as hypolipidemic and antioxidant agent, in prevention of lipid elevation in rats fed on high cholesterolemic diet, also helps as natural antioxidant in decreasing the chance of disease progression and using the leaves powder in producing type of functional bakery product.

\section{Materials and methods}

\subsection{Materials}

Moringaoleifera leaves were harvested from the Aschrafsaad Farm, Elbuhera Governerate .Commercial wheat flour was obtained from the local market. All chemicals were of analytical grade and purchased from Sigma Chem. Co., (St. Louis, MO, USA), Merck (Germany), and Bipdigonostic 1Chems Co. (Egypt).

\subsection{Methods}

Moringaoleifera leaves were dried in an oven at $50^{\circ} \mathrm{C}$ for 8 hours ,the dried leaves were ground and sieved using sieve (20 mesh) and kept in the refrigerator until needed.

\subsubsection{Proximate composition}

On dry powder, the chemical composition of dry components such as protein, fat, crude fiber, and ash was measured. according to association of Official Analytical Chemists (A.O.A.C, 2016), total carbohydrates were calculated by difference (Valdez-Solana et al., 2015).The atomic absorption method was used to determine minerals including calcium, phosphorus, and iron. (A. Analysit 400.perkineler), (Mouminah, 2015).

\subsubsection{Determination of antioxidants}

$10 \mathrm{gm}$ of MOLP were dissolved in $100 \mathrm{ml}$ boiling water with swirling for 30 minutes, then filtered using filter paper NO (1), and centrifuged for $30 \mathrm{~min}$ at $2000 \times \mathrm{g}$, then stored for analyses at $-20^{\circ} \mathrm{C}$ (Sarkar et al.,2017).

\subsubsection{Determination of ascorbic acid:-}

The ascorbic acid content was measured by titration method using 2,4-Dichloro-phenolIndophenol dye A.O.A.C. (2016).

2.2.1.3.Determination of total polyphenols and flavonoids

Total polyphenols content of leaves extract of $M$. oleifera was measured as gallic acid calculated using the method of ciocalteu's. Total flavonoids in leaves extract was assayed with colorimetric method using aluminium chloride and expressed as quercetin equivalent (Akter et al., 2015).

2.2.2.4.Evaluation of free radical scavenging activity

The free radical scavenging activity of the $M$ Moringaoleifera leaves extract-picryl-hydrazyl (DPPH) was determined according to (Akter et al., 2015) by determining the absorbance decreasing of the DPPH solution at $517 \mathrm{~nm}$ in methanolic extract.

$\%$ Inhibition $=\left[\left(\mathrm{A}_{\mathrm{c}}-\mathrm{A}_{\mathrm{s}}\right) / \mathrm{A}_{\mathrm{c}}\right] \times 100$

$\mathbf{A}_{\mathbf{c}}$ : Absorbance of control

$\mathbf{A}_{\mathrm{s}}$ : absorbance of sample

\subsection{Experimental animals}

Thirty six male albino rats with a body weight ranging $130 \pm 10 \mathrm{~g}$ were obtained from animal house of National Organization for Drug Control and Research(NODCAR) Giza, Egypt. 
The animals were kept in cages for a week to acclimatize under standard conditions included 12/12 hour dark/light cycle, relative humidity, and free access to water and food. The investigation complies with the guide for the care and use laboratory animals (NODCAR/II/28/20).Six rats(initial group) were randomly chosen, then weighed, blood samples were obtained from retrobulbar venous plexus of each rat (Shermer and Jones,1967). The serum was separated and its biochemical parameters were determined, then rats were sacrificed and liver was excised and subjected to its tissue biochemical analysis.

The reminder rats were divided into five groups each of 6 rats as follows:

control: Rats fed on basal diet control+: Rats fed on high cholesterol diet (HCD) containing cholesterol (1.25\%) and bile acids( $0.5 \%)$ (Panduet al., 2018)

Gr I : Rats fed on HCD and M. oleifera leaves powder(MOLP), 250mg $/ \mathrm{Kg}$

Gr II : Rats fed on HCD and MOLP500 mg/Kg Gr III: Rats fed on HCD and MOLP750mg/Kg

Feeding duration was 45 days, changes in body weight were recorded and blood samples were taken at time intervals 15, 30 and 45 days, then serum was separated and subjected to the biochemical analysis. Rats were sacrificed at the end of the experiment, and the liver was excised and subjected to tissue biochemical analysis.

\subsubsection{Serumbiochemical analysis}

Serum total lipids were determined according to (Zoliner and Kirsch,1962), triglycerides(TG) were determined according to(Fossati, 1982) totalcholesterol (TC) was determined according to(Allain et al., 1974),HDL-Cholesterol(HDL-C) was determined according to the method of (LopezVirella,1977) and LDL -cholesterol(LDL-C) was calculated (Salamatullah et al.,1983)

\subsubsection{Tissue biochemical parameters}

One gram of liver was homogenized in $9 \mathrm{~mL}$ of ice cold saline and centrifuged at $6000 \mathrm{xg}$ for 10 minutes, then TC and TG were determined in the supernatant

(Zhanga et al., 2013).

\subsection{Preparation of crackers}

The flour formulations which used to make cracker samples were produced in various ratio as follow: :

control: $100 \mathrm{~g}$ wheat flour .

Sample A: $75 \mathrm{~g}$ wheat flour $+25 \mathrm{~g}$ MOLP

B: $50 \mathrm{~g}$ wheat flour $+50 \mathrm{~g}$ MOLP

$\mathrm{C}: 25 \mathrm{~g}$ wheat flour $+75 \mathrm{~g}$ MOLP

The dough of products was prepared by mixing each above mixture with corn oil, active yeast, salt and spices mixture(Abd-El Rahim, 2005), conditions of baking were adjusted as: Temperature for fermentation $30^{\circ} \mathrm{C}$ for 30 minutes, then bake at $200^{\circ} \mathrm{C} / 15$ minutes(Saba, 1993).

\subsubsection{Rheological measurements}

Rheological measurements for flour mixtures were carried out using farinograph and extensograph tests(A.A.C.C, 2007). The parameters including; water absorption, dough development time, stability time, degree of softening and elasticity were determined using farinograph Brabender OHG Duisurg kulturstrasse 51- 55. extensibility P.N and energy of the dough were determined using Brabender extensograph device .

\subsubsection{Sensory evaluation}

The staff members were chosen as twenty panelists to test the crackers' sensory properties. Indication of preference was madeon a scale of evaluation to 10 for each of sensory characteristic namely ; appearance, color, flavor, Oder, taste and acceptability(Abd-El Rahim, 2005).

\subsection{Statistical analysis}

The data can be displayed as mean \pm standard error and analyzed using one-way ANOVA, followed by Tukey post-hoc test, using Graph Pad Prism data analysis program (Graph Pad software, Inc., San Diego, CA, USA). A value of $p \leq 0.05$ was considered statistically significant. 


\section{Results and discussions}

\subsection{Nutritional composition of}

Moringaoleifera leaves powder

The proximate chemical composition of Moringa oleifra leaves powder(MOLP) on dry basis was shown in tab(1),Protein content was $30.29 \%$ protein values ranged from 22.60 to $38.25 \%$ according to(Lesten and Emmanuel, 2018),M. leaves contain a high-quality protein that is easy to absorb and is determined by the amino acids quality.(Mune et al., 2016).Fat content value was $5.4 \%$ as seen in Table (1), ether extract for air dried M.leaves has a fat content of 6.5\%.(Busani et al., 2011).The results also showed that ash content of leaves powder was $8.96 \%$, ash content ranging from 4.60 to $11.24 \%(L e s t e n$ and Emmanuel, 2018), the high ash content of $\mathrm{M}$. leaves indicates that they are a good source of minerals(Shokry, 2017).

On the other hand, the percentage of fiber content was $9.2 \%$ as seen in table (1).Fibers content of M. leaves was $8.96 \%$ (Aye and Adegun, 2013). Fibers are important part in a healthy balanced diet; prevent weight gain, improve digestive, diabetes, heart disease, and some cancer diseases (Shokry, 2017), also the ability of fiber to absorpt water led to positive effect against constipation(Gatade et al.,2013). However the percentage of carbohydrates of dried leaves was $46.15 \%$ calculated by difference which confirmed with Rajput et al., (2017).

Table 1. Nutritional composition of Moringaoleifera leaves powder on dry basis $(\mathrm{g} / 100 \mathrm{gm})$

\begin{tabular}{|l|l|}
\hline \multicolumn{2}{|c|}{ Parameters } \\
\hline Protein & $30.29 \pm 1.04$ \\
\hline Fat & $5.4 \pm 0.09$ \\
\hline Ash & $8.96 \pm 0.08$ \\
\hline Crude Fiber & $9.2 \pm 0.34$ \\
\hline Total Carbohydrate & $46.15 \pm 0.11$ \\
\hline Mineral : & \\
\hline Calcium & $3.60 \pm 0.08$ \\
\hline Phosphorus & $0.198 \pm 0.02$ \\
\hline Iron & $0.021 \pm 0.07$ \\
\hline
\end{tabular}

Mean \pm SE, $n=3$
The leaves of $M$. oleifera contain high amount of calcium in value of $3.60 \mathrm{~g} / 100 \mathrm{~g}$ and very high amount of Phosphorus and iron in values of $0.198 \mathrm{and} \quad 0.021 \mathrm{~g} / 100 \mathrm{~g}$ powder respectively as seen in table (1)calcium are required for a range of activities in the body, including the bones and teeth. Iron, as the nucleus of hemoglobin, is required for the production of red blood cells in the body.(Mulyaningsih and Yusuf, 2018).

\subsection{Antoxidants content of Moringaoleifera leaves powder:}

Ascorbic acid content was $0.51 \mathrm{mg} / \mathrm{g}$ as seen in table (2).Content of ascorbic acid ranged from56 to $129 \mathrm{mg} / 100 \mathrm{~g}$ (Hanson et al., 2006).There was a significant difference in ascorbic acid content in plant parts(Asghari et al., 2015).Ascorbic acid is good source for cardiovascular health and the suppression of free radicals in cells.(Sohaimy et al.,2015).

Phenolic compounds and flavonoids are very important constituents due to its antioxidative activity. Phytochemical compounds including ; phenols and flavnoids, are shown in table (2) in values of $71.65 \mathrm{mg}$ gallic acid $/ \mathrm{g}$ for phenols and $8.43 \mathrm{mg}$ querctin / $\mathrm{g}$ for flavonoids. Querctin content in M. oleifera leaves was found in range from 0.46 to $16.64 \mathrm{mg} / \mathrm{g}$ (Amaglo et al., 2010).

Table 2. Phytochemicals content of Moringaoleifera leaves powder (mg/g).

\begin{tabular}{|l|l|}
\hline \multicolumn{2}{|c|}{ Parameters } \\
\hline Ascorbic acid & $0.51 \pm 0.11$ \\
\hline $\begin{array}{l}\text { Total phenols } \\
\text { (equivalent galic acid) }\end{array}$ & $71.65 \pm 0.89$ \\
\hline $\begin{array}{l}\text { Total flavonoieds } \\
\text { (querctin equivalent) }\end{array}$ & $8.43 \pm 0.17$ \\
\hline
\end{tabular}

Mean \pm SE, $\mathrm{n}=3$

The total phenolic content ranged between 37.7 to $137.53 \mathrm{mg}$ gallic acid /g and the total flavonoids content ranged between 8.22 to 33.40 (mg QE/g) in Moringa peregrine and M.oleifera extracts, respectively (El-awadyet al., 2016). Antioxidant from natural source helps in scavenging free radicals and improve the 
antioxidant system in body. An increasing in the interest for antioxidant from natural source faster than synthetic sources, M.oleiferais rich in phenolic compound which can reduced many diseases as antioxidant compound(Andréa et al.,2012).

\subsection{Antioxidant activity of Moringa oleifera leaves powder:}

Antioxidant activity at various concentrations of MOLP20,40,80 and $100 \mu \mathrm{g} / \mathrm{ml}$ were evaluated and the results are presented in fig (1 ). The results showed inhibition of 2, 2diphenyl-1-piccrlhydrazyl hydrate (DPPH) radicals in percentage values of; $42.44,46.64,55.49,60.49$ and 67.11 in the above concentrations respectively. The antioxidants activity of M. leaves was found between 59.8 to 40.4(Pakade et al., 2013).DPPH radical scavenging assay for MOLP was used as one of indicated that It can be used in food products as an antioxidant source.

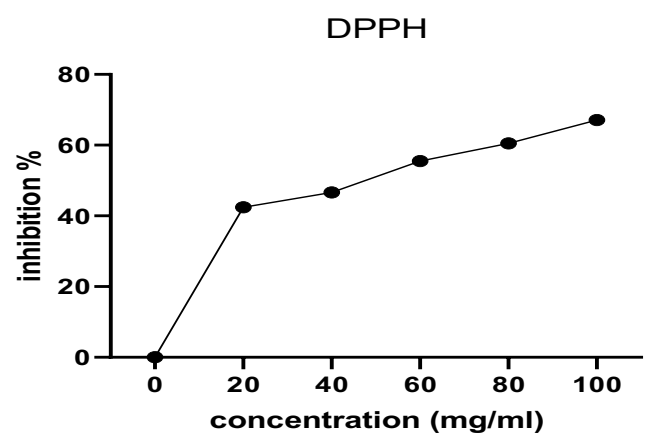

Figure 1.DPPH radical scavenging activity of Moringaoleiferaleaves extract

\subsection{Biological evalution}

\subsubsection{Effect on body weight}

The results showed the effect of administration the three doses of MOLP; 25 , 500 and $750 \mathrm{~g} / \mathrm{kg}$ diet on rats fed on high cholesterol diet for 45 days. The changes in body weight in the five groups during the experimental period were found in table (3). There was non significant differences in body weight among all groups at the beginning of the experiment, gradually increasing in body weight was found during feeding period till the end of experiment in positive control group which was fed on high cholesterol diet compared to the negative control group in values of 106.20 and $40.84 \mathrm{~g}$ in the weight gain of the two groups respectively. The obese status of rats was maintained when they were fed a high fat diet for two weeks. Also there was a significant difference in the body weight between positive control group which was fed on HCD and tested groups I, II and III which were fed on HCD and different ratios of MOLP, the increasing in all tested groups ranged between27.39to 60.74g.From the aforementioned data, it can be seen that the least values in body weight gain was obtained in rats fed on HCD and $75 \mathrm{~g} / \mathrm{kg}$ diet of MOLP(III) followed by II , then group I which were fed on MOLP in values of 50 and $25 \mathrm{~g} / \mathrm{kg}$ diet respectively. While compared to rats fed a highfat diet, MOLP supplementation at 200 and 400 $\mathrm{mg} / \mathrm{kg}$ b.w. reduced body weight gain and resulted in a significant reduction in body weight(Bais et al., 2014), which led to inhibition in HMG COA reductase activity, that is the key enzyme in pathway of cholesterol biosynthetic, or because of inhibition in body tissues cholesterol deposition. (Atsukweilet al.,2014) 
Table 3.Changes in body weight ( $\mathrm{g}$ ) of male rats fed on high cholesterol diet supplemented with Moringa oleifera leaves powder.

\begin{tabular}{|c|c|c|c|c|c|}
\hline \multirow{2}{*}{$\begin{array}{l}\text { Animal } \\
\text { Group }\end{array}$} & Initial & \multicolumn{3}{|c|}{ Feeding period (days) } & \multirow{2}{*}{$\begin{array}{c}\text { Body } \\
\text { weight gain } \\
\text { (g) } \\
\end{array}$} \\
\hline & $\mathbf{0}$ & 15 & 30 & 45 & \\
\hline Control $^{-}$ & $123.96^{\mathrm{a}} \pm 0.42$ & $133.71^{\mathrm{a}} \pm 0.55$ & $153.46^{\mathrm{c}} \pm 0.44$ & $164.80^{\mathrm{a}} \pm 0.42$ & 40.84 \\
\hline control $^{+}$ & $121.03^{\mathrm{a}} \pm 0.38$ & $152.80^{c} \pm 0.64$ & $194.77^{\mathrm{e}} \pm 0.42$ & $227.23^{\mathrm{d}} \pm 5.30$ & 106.20 \\
\hline Group I & $124.13^{\mathrm{a}} \pm 0.53$ & $143.74^{\mathrm{d}} \pm 0.57$ & $163.17^{\mathrm{d}} \pm 0.95$ & $184.77^{\mathrm{c}} \pm 0.42$ & 60.74 \\
\hline II & $125.98^{\mathrm{a}} \pm 0.31$ & $137.42^{b} \pm 0.44$ & $150.15^{\mathrm{b}} \pm 0.59$ & $156.64^{\mathrm{ab}} \pm 0.56$ & 30.66 \\
\hline III & $124.12^{\mathrm{a}} \pm 0.36$ & $136.09^{b} \pm 1.37$ & $143.78^{\mathrm{a}} \pm 0.51$ & $151.51^{\mathrm{a}} \pm 0.71$ & 27.39 \\
\hline
\end{tabular}

$\mathrm{n}=6$ rats

control $^{-}$: rats fed on basal diet, control $^{+}$rats fed on high cholesterol $\operatorname{diet}(\mathrm{HCD})$.

Group I : rats fed on HCD + MOLP(25g/kg diet), Group II : rats fed on HCD + MOLP(50 g/kg diet).

Group III: rats fed on HCD +MOLP(75 g/kg/diet), Mean \pm SE, a, b, c, d e: Significantly different tasted groups ; I , II and III from control $^{-}$or control ${ }^{+}$for at $\mathrm{P}<0.05$ using one way ANOVA followed by Tukey as post-hoc test

\subsubsection{Effect on glucose}

Data in fig(2) showed a significant $(p<0.05)$ increase in glucose level in the positive control group which was fed on high cholesterol diet compared to negative control group which was fed on standard diet at the end of experimental period in values of 229.55 and $90.82 \mathrm{mg} / \mathrm{dl}$ in the two groups, respectively. On the other hand, Blood glucose levels decreased significantly $(p<0.05)$ in all studied groups but the highest effective was observed in group III which was fed on HCD and MOLP, $75 \mathrm{~g} / \mathrm{kg}$ diet followed by group II then group I as seen in fig(2) in values of $94.64,141.46$ and $160.74 \mathrm{mg} / \mathrm{dl}$, Also, non significant differences between group III and negative control group was found in percentage values of 94.64 and $90.82 \mathrm{mg} / \mathrm{dl}$ after the end of experiment, respectively. Moringa leaves caused a significant reduction in blood glucose levels in waster rats with type 2 diabetes.(Ndong et al.,2007), also, another study reported as a mechanistic model for anti-diabetic activity, that the extract from $M$. leaves is effective for reducing sugar within 3 hours of ingestion(Mittall et al., 2007).

On the other hand, Moringa leaves were shown to have beneficial effects on carbohydrate metabolism with different mechanisms including; improving glucose uptake and utilization, increasing insulin activity, restoring and preventing the integrity and function of $\beta$ cells (Vergara-Jimenez et al., 2017), the dried leaves or aqueous extract of M. oleifera were more effective and may be it have some effect by increasing the glucose utilization in tissue by inhibiting absorption of glucose or hepatic gluconeogenesis into the muscles and adipose tissue(Gray et al.,2000)

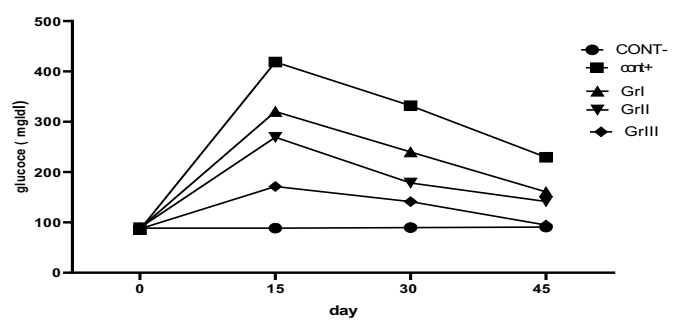

Figure 2. Serum glucose $(\mathrm{mg} / \mathrm{dl})$ in rats fed on high cholesterol diet and different ratios of Moringa oleifera leaves powder for 45 days. ( $n=6$ rats). Groups abbreviations as seen in table(3) 


\subsubsection{Effect on total lipids}

The results in fig (3) showed highly significant increasing in serum total lipids in positive control feeding with diet containing $0.5 \%$ cholesterol compared to negative control group which was fed on basal diet in values of 628.96 and $337.37 \mathrm{mg} / \mathrm{dl}$ in the two groups respectively the results were in agreement with Muniz et al., (2019)The tested groups I, II and III which were fed on HCD and different concentrations of MOLP, showed gradually significant decreases in total lipids compared to positive group, the highest decrease was found in group III then group II then group I which were fed on HCD supplemented with MOLP in concentration of 75,50 and $25 \mathrm{~g} / \mathrm{kg}$ diet in the three groups respectively, the decreases were in values of $313.83,467.50$ and $501.50 \mathrm{mg} / \mathrm{dl}$ in the three groups, respectively.

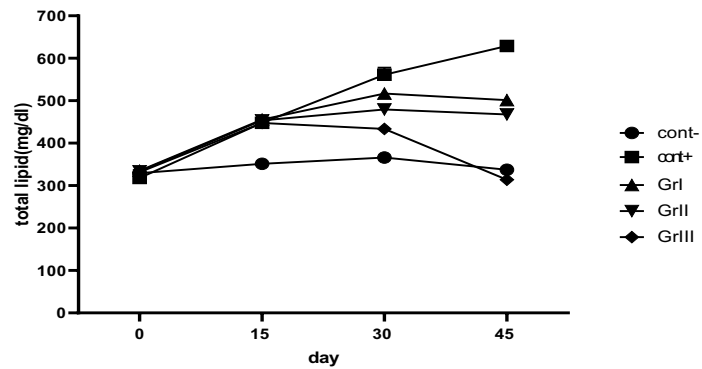

Figure 3.Serum total lipids $(\mathrm{mg} / \mathrm{dl})$ in rats fed on high cholesterol diet and different ratios of Moringa oleifera leaves powder for 45 days. ( $n=6$ rats).Groups abbreviations as seen in table(3)

\subsubsection{Effect on triglycerides}

The results in fig(4) showed significant increases in triglycerides in positive control group compared to negative control group in values of 276.43 and $87.02 \mathrm{mg} / \mathrm{dl}$, respectively. On the other hand, tested groups showed also significant gradually decreases in triglycerides during feeding period, the highest decreases was observed in group III followed by group II , then group I in values of 99.88, 105.31 and 135.57, in the three groups respectively compared to positive and negative control rats in values of 276.43 and $87.02 \mathrm{mg} / \mathrm{dl}$ respectively, the content of flavonoids and vitamin $\mathrm{C}$ in M oleifera can lower TG and LDL-C levels as a result for the inhabitation of 3-Hydroxy-3-methyglutary Coenzyme A (HMG$\mathrm{CoA}$ ) reductase this decomposition of cholesterol, LDL-C, TG become slow which results in the formation of cholesterol, LDL-C and TG decreased ,also, triacylglycerols are storage form of fatty acids(Affanet al., 2018).the improved serum values of TG, TC, LDL-C, and VLDL-C that were observed simultaneously in the study, the lowering in total lipids in treated animals is logical.(Atsukweil et al., 2014;Gheith and El-Mahmoudy, 2019) .

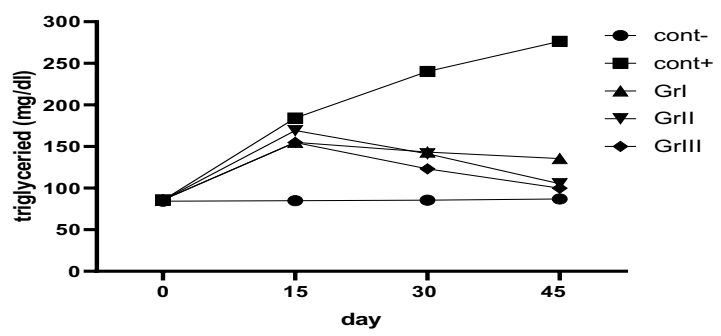

Figure 4.Serum triglycerides $(\mathrm{mg} / \mathrm{dl}))$ in rats fed on high cholesterol diet and different ratios of Moringa oleifera leaves powder for 45 days. ( $\mathrm{n}=6$ rats). Groups abbreviations as seen in table(3). 


\subsubsection{Effect on Total-cholesterol, LDL- cholesterol and HDL-cholesterol}

As shown in fig (5), positive control group which was fed on basal diet containing $1.25 \%$ cholesterol for 45days showed significantly increases in serum parameters including; $\mathrm{TC}$, LDL- $\mathrm{C}$ and decrease in HDL- $\mathrm{C}$ in values of 205.24, 126.25 and $19.04 \mathrm{mg} / \mathrm{dl}$ compared to negative control group in values of $82.71,28.40$, and $53.93 \mathrm{mg} / \mathrm{dl}$ at the end of experiment in the aforementioned parameters, respectively.

Total cholesterol and LDL-C were decreased significantly $(\mathrm{P}<0.05)$ in all tested groups ; I, II and III which were given different concentrations from MOLP ; 25,50 and $75 \mathrm{~g} / \mathrm{kg}$ diet at the end of experiment in values of 115.79 ,
98.51 and $90.97 \mathrm{mg} / \mathrm{dl}$ and $32.30,30.25$ and $27.45 \mathrm{mg} / \mathrm{dl}$ in the two parameters respectively compared to positive control rats in values of 205.24 and $126.25 \mathrm{mg} / \mathrm{dl}$ as seen in figure (5) A and $\mathrm{B}$. Moringa oleifera leaves containing $\beta$ sitosterol inhibit the cholesterol absorption in the intestines, which limit the ability of the cholesterol entrance to the body, and helps in reducing cholesterol limit (Frawley, 2009), similarity of B-sitosterol and cholesterol led to it takes place of micelles cholesterol in the intestinal lumen, which caused reduction in cholesterol absorption, and will be absorbed in stead of cholesterol. Reduced cholesterol caused reduction in LDL-C, which carries cholesterol to the blood serum from liver(Rana et al.,2007).
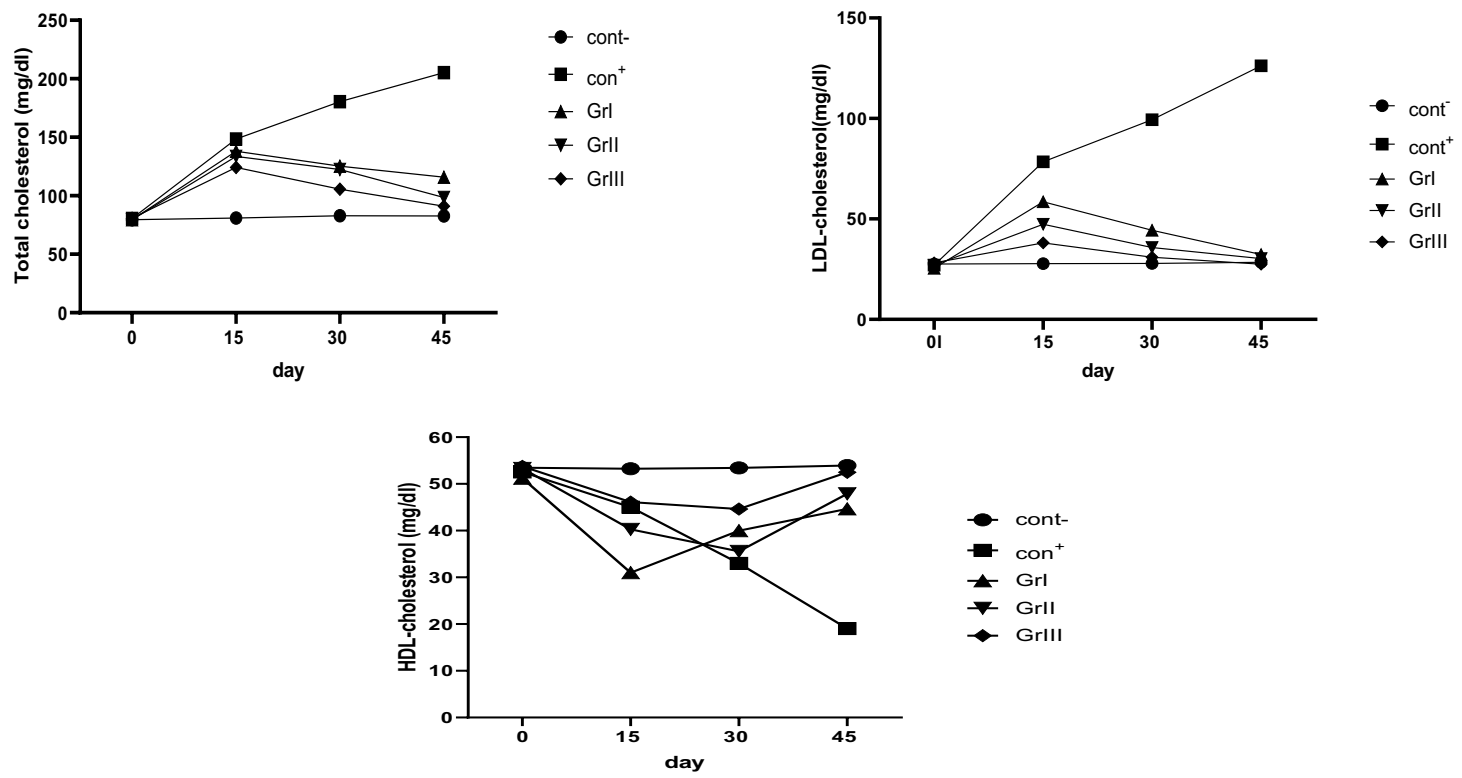

Figure 5(A-C). Serum total cholesterol, HDL and LDL cholesterol (mg/dl) in rats fed on high cholesterol diet and different ratios of Moringa oleifera leaves powder for 45 days. ( $n=6$ rats). Groups abbreviations as seen in table(3)

Acetyl-CoA is important as a key substrate in cholesterol biosynthesis, extract of Moringa oleifera at $600 \mathrm{mg} / \mathrm{kg}$ body weight lead to a decrease in acetyl CoA concentration, leading to low -oxidation of fatty acid.(Atsukwei, 2014).Also, HDL-cholesterol was increased significantly $(\mathrm{P}<0.05)$ in all the tested groups which were given different ratios of MOLP for 45 days as seen in figure (5C). The highest increase was found in group III , followed by group II then group I which were fed on supplemented diet with MOLP in 75,50and $25 \mathrm{~g} / \mathrm{kg}$ diet respectively, the increase was in values of $52.48,47.89$ and $44.67 \mathrm{mg} / \mathrm{dl}$, respectively.

Oral administration of $\mathrm{M}$ leaves extract to rats at dose of 100 and $200 \mathrm{mg} / \mathrm{kg}$ b.w for 28 days improved HDL-C levels.(Ma et al., 2018). 
Also, the treated group which was given $4.6 \mathrm{~g}$ of leaves powder in tablet form had a $1.6 \%$ decrease in cholesterol and $6.3 \%$ rise in HDL compared to the control group(Stohs and Hartman, 2015), $M$. leaves extracts at doses of 300 and $600 \mathrm{mg} / \mathrm{kg}$ b.w, significantly decreased TG, TC, LDL-C, VLDL-C, atherogenic index, and increased HDL-C in rats fed on high-fat diet (Jain et al., 2016).

\subsubsection{Effect on liver enzymes}

The data in fig 6 (A-B) showed a significant increase in the activity of all liver enzymes Alanin aminotransferase (ALT) and Aspartate amino transferase (AST) in control positive group fed on HCD in values of 60.97 and $47.60 \mathrm{mg} / \mathrm{dl}$. compared to the normal control group in values of 42.89 and $40.73 \mathrm{mg} / \mathrm{dl}(\mathrm{P}<$ $0.05)$ respectively, when compared to other tested groups that had a significant decline in liver enzyme activities, after administration of different concentrations of MOLP.

Also group ;I, II and III fed on HCD and MOLP showed significant improvement in serum ALT and AST activity at the end of experiment in the values of 44.71 and 44.94 for group I,41.56 $\mathrm{mg} / \mathrm{dl}$ and 41.08 for group II , 41.78and $39.64 \mathrm{mg} / \mathrm{dl}$ for group III for the two parameters compared to positive control rats in values of 60.97 and $47.60 \mathrm{mg} / \mathrm{dl}$ respectively $(\mathrm{P}<0.05)$. In mice fed a high fat diet, hepatoprotective properties of MOLP were found to protect against liver damage by lowering (AST) and (ALT)(Nilanjan Das et al., 2012), ALT and AST measurement is of clinical and toxicological importance because their activity indicates tissue damage by toxicants or in disease condition liver (Rania et al., 2016). Feeding on high fat diet with Moringa oliefera at 3\% \& 5\% caused decrease in serum AST and ALT as compared to positive control group(Etab and Mona, 2017).Also Moringa oleifera fortified diet improves liver functions, in addition it can protect the liver from chemically induced (Buraimoh, 2011).

\subsubsection{Effect on Liver lipid}

Total cholesterol and triglycerides in liver were shown in fig 7(A-B) with higher level in positive high fat group in values of 315.07 and $200.59 \mathrm{mg} / \mathrm{dl}$ than that of negative group in values of 95.72 and $123.59 \mathrm{mg} / \mathrm{dl}$ for the two parameters respectively. Tested groups; I, II and III showed significant decrease in both parameters with the highest decrease level in group III in values of 132.49 and $108.96 \mathrm{mg} / \mathrm{dl}$ followed by group II in values of 77.69 and $96.49 \mathrm{mg} / \mathrm{dl}$ then group I in values of 112.49 and $108.96 \mathrm{mg} / \mathrm{dl}$ compared to positive group with values of 315.07 and $200.59 \mathrm{mg} / \mathrm{dl}$ respectively.

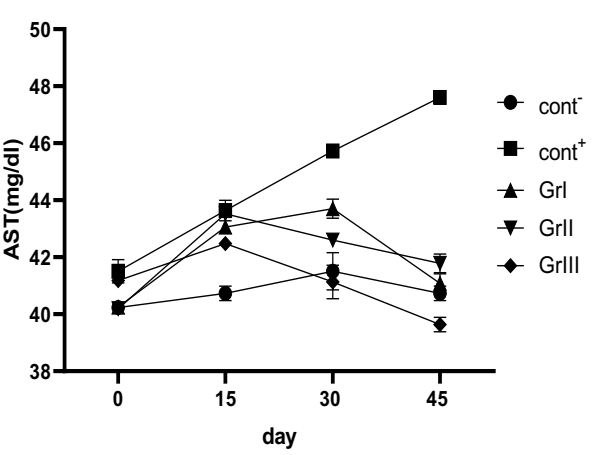

Figure 6(A-B). Serum ALT and AST (mg/dl) in rats fed on high cholesterol diet and different ratios of Moringa oleifera leaves powder for 45 days. ( $\mathrm{n}=6$ rats) Groups abbreviations as seen in table(3). 

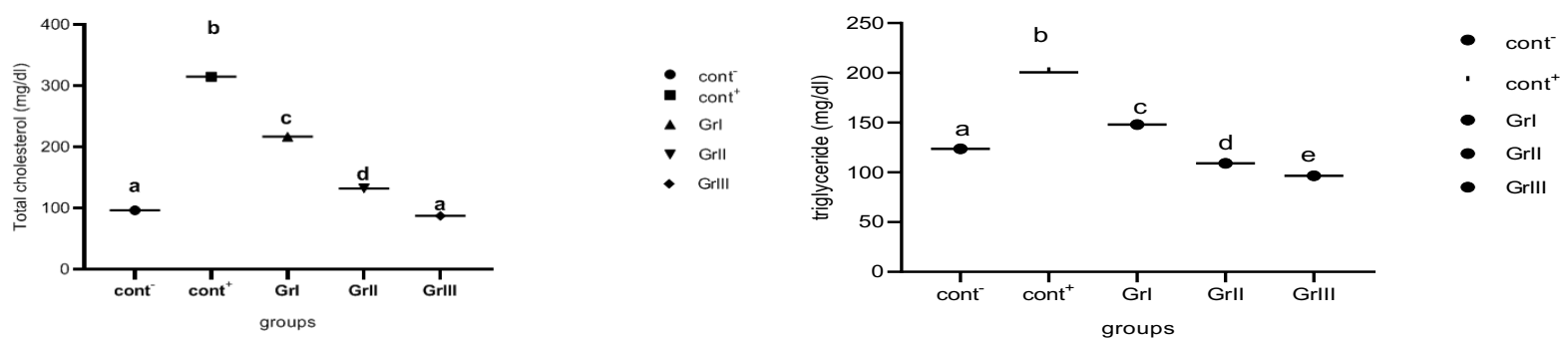

Figure 7(A-B). liver total cholesterol and triglyceride $(\mathrm{mg} / \mathrm{dl})$ of rats fed on high cholesterol diet and different ratios of Moringa oleifera leaves powder for 45 days. $n=6$ rats. Groups abbreviations as seen in table(3).

The changes in high fat group were recovered in both tested groups and the values were less than that in negative group, the best results were found in groups III followed by group II. Moringa oleifeara leaves extract improved the status of liver disease in mice feeding high fat diet and can protect the liver from the hepatotoxic drugs and toxins(Nilanjanet al.,2012)

\subsection{Rheological properties}

The dough's rheological properties were determined using farinograph and Extensograph, which showed non response and could not obtained any results for the two dough samples contain 50 and 75\%MOLP,only sample contains $25 \%$ showed clear results.

\subsubsection{Farinograph parameters}

Rheological properties of dough, which are important for dough quality were determined using pharinograph for dough prepared from wheat flour supplemented with MOLP(25\%) and control sample contain wheat flour $100 \%$ ,The result is presented in table (4.A-B) ).

The results in this study showed increasing in water absorption in tested sample compared to control sample in percentage values of 75.0 and $61.5 \%$ respectively. Damage starch content and soluble protein may influence water absorption(Rakszegi et al., 2014).Results in table (4A) showed also equal arrival time in value of one minute for both tested and control samples. On the other hand increasing in dough development time in tested sample was observed which is the need time to mix flour and water to form dough with the best consistency compared to control sample in values of 3.5 and $1.5 \mathrm{~min}$ in the two groups, respectively. Development time of dough which was determined with pharinograph ranged from 1.8 to $4 \mathrm{~min}$ (Pelin and Incilay, 2020).

The stability value was decreased in strength of the tested dough compared to control in values of 4.5 and 5.5 min as seen in table (4A). Normal stability by pharinograph ranged from 2.3 to 10 min, also dough stability for MOLP- wheat flour tested sample was around $5 \mathrm{~min}$ (Pelin and Incilay, 2020) .

\subsubsection{Extensograph parameters:}

Extensograph was used to determine resistance and extension ability of the dough, data in table (4B) and figure(7B)showed the results of extensograph analysis of parameters for tested sample supplemented with $\operatorname{MOLP}(25 \%)$ and control sample contains wheat flour $(100 \%)$.Elasticity and extensibility were decreased in tested sample compared to control sample in values of 180 and 320(B.U)in the two samples respectively, the same trend was in agreement with Rania et al.,(2016).proportional number which calculated from elasticity and extensibility was increased in tested sample contains MOLP(25\%),compared to control group in values of 5.14 and 1.94 P.N., respectively. Finally dough energy had the highest value in control in value of $105 \mathrm{~cm}^{3}$, these results are in agreement with those obtained by Rania et al.,(2016) and ElKaramany, (2015 
Table 4.Farinograph and Extensograph parameters for control and tested dough supplemented with Moringa oleifera leaves powder(25\%)

(A)

\begin{tabular}{|l|c|c|c|c|}
\hline Parametres & $\begin{array}{l}\text { Water } \\
\text { absorption } \\
\text { \%omple }\end{array}$ & $\begin{array}{l}\text { Arrival } \\
\text { time } \\
\text { (min) }\end{array}$ & $\begin{array}{l}\text { Dough } \\
\text { development } \\
\text { (min) }\end{array}$ & $\begin{array}{l}\text { Degree of } \\
\text { softening } \\
\text { (B.U) }\end{array}$ \\
\hline Control & 61.5 & 1.0 & 1.5 & 50 \\
\hline Sample A & 75.0 & 1.0 & 3.5 & 180 \\
\hline
\end{tabular}

(B)

\begin{tabular}{|l|c|c|c|c|}
\hline \multicolumn{1}{|c|}{ parameters } & $\begin{array}{c}\text { Elasticity } \\
\text { (B.U) }\end{array}$ & $\begin{array}{c}\text { Extensibility } \\
(\mathbf{m m})\end{array}$ & $\begin{array}{c}\text { Proportional } \\
\text { number } \\
\text { P.N }\end{array}$ & $\begin{array}{c}\text { Energy } \\
\left(\mathbf{c m}^{\mathbf{2}}\right)\end{array}$ \\
\hline Control & 320 & 165 & 1.94 & 104 \\
\hline Sample A & 180 & 35 & 5.14 & 12 \\
\hline
\end{tabular}

Control: $100 \%$ wheat flour Sample

Sample A: $75 \%$ wheat flour $+25 \%$ Moringa oleifera leaves powder
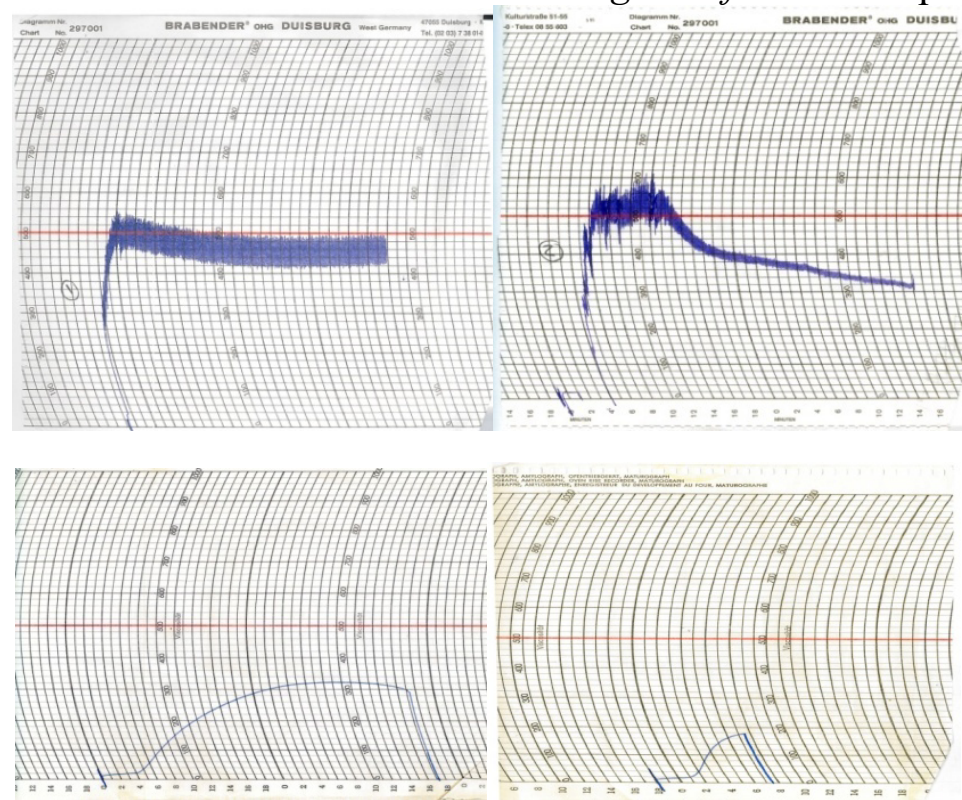

Control

Sample (A)

Figure 8 (A-B).Farinograph and Extensograph parameters for control and tested dough supplemented with Moringa oleifera leaves powder(25\%)

\subsection{Sensory evaluation of crackers :}

Data in fig. (9) show sensory evaluation of crackers manufactured with MOLP25\%.
Significant differences $(\mathrm{P}<0.05)$ in all sensory evaluation compared to control (A) were found. 


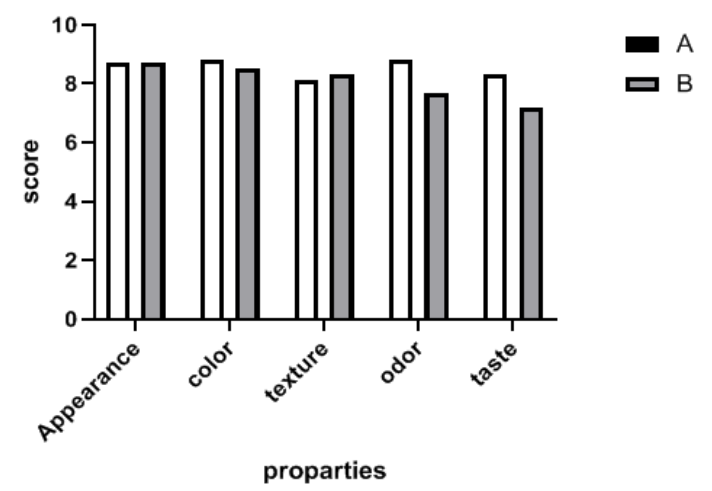

Figure 9.Sensory evaluation of crackers prepared from dough supplemented with (25\%) Moringa oleifera leaves powder.

\section{Conclusions}

Hypolipidemic and antioxidative effect of different ratios of MOLP were studied; therefore its chemical composition was determined and the biological evaluation on male rats were estimated. Supplemented dough containing different ratios of MOLP were prepared, and dough which showed the best rheological parameters $(25 \%)$ was used to manufacture crackers, that can be used as hypolipidemic and antioxidative functional food with acceptable sensory characteristics. This study indicated that MOLP can be used as natural source in production of hypolipidemic and antioxidative functional food.

\section{Reference}

A.A.C.C. (2007). American Association of Cereal Chemists. Approved methods of AACC.10th ed. St. Paul. Minnesota. USA. Chemists 15 (Ed) Washington DC, 22, 1-11.

A.O.A.C. (2016). fficial methods of analysis of AOAC international 20th(ed) current through revision 2. ATKINSON, M. A. FURTH, S. L. $2011 .$.

Abd-El Rahim, E. A. (2005). Influence of brown rice and corn starch blends as main ingredients for production of some gluten free products. Egyption Journal Nutration, 20, 195-214.

Adedapo, A. A., Mogbojuri, O. M., Emikpe, B. O. (2009). Safety evaluations of the aqueous extract of the leaves of Moringa oleifera in rats. Journal of Medicinal Plants Research, 3(8), 586-591.

Affan, M., Hadisaputro, S., Semarang, Kemenkes, P. (2018). The effect of Moringa oleifera on blood pressure and high-density lipoprotein in hypertension patients with hypercholesterolemia. Nternational Journal of Multidisciplinary Education and Research International, 3(5), 27-30.

Akter, F., Haque, M., Islam, J., Rahman, A., Bhowmick, S., Hossain, S. (2015). Chronic administration of Curcuma longa extract improves spatial memory-related learning ability in aged rats by inhibiting brain cortico-hippocampal oxidative stress and TNF? Advances in Alzheimer's Diseases, 4(3), 78-89.

Alattar, A. A. (2006). Comparative Physiological Study on the Effect Rosemary, Tarragon and Bay Leaves Extract on Serum Lipid Profile of Quail, Coturnixcoturnix. Saudi. J. of Biol. Sci., 13(2), 1-98.

Allain, C.C.; Poon, L.S. and Chan, C. (1974). Enzymatic determination of total serum cholesterol. Clin. Chem, 20, 470-475.

Amaglo, N. K., Bennett, R. N., Lo Curto, R. B., Rosa, E. A. S., Lo Turco, V., Giuffrida, A., Timpo, G. M. (2010). Profiling selected phytochemicals and nutrients in different tissues of the multipurpose tree Moringa oleifera L., grown in Ghana. Food Chemistry, 122(4), 1047-1054. 
Andréa, F. S. Santos, Adriana C. C. Argolo, P. M. G. P. L. C. B. B. C. (2012). Antioxidant Activity of Moringa oleifera Tissue Extracts. Phytother. Res., 26, 1366-1370.

Asghari, G., Palizban, A., Bakhshaei, B. (2015). Quantitative analysis of the nutritional components in leaves and seeds of the Persian Moringa peregrina ( Forssk .) Fiori. Pharmacognosy Research, 7(3), 242-248.

Atsukwei, D. (2014). Hypolipidaemic Effect of Ethanol Leaf Extract of Moringa Oleifera Lam. in Experimentally induced Hypercholesterolemic Wistar Rats. International Journal of Nutrition and Food Sciences, 3(4), 355.

Atsukwei, D., Eze, E. D., Adams, M. D., Adinoyil, S. S., Ukpabi, C. N. (2014). Hypolipidaemic Effect of Ethanol Leaf Extract of Moringa Oleifera Lam. in Experimentally induced Hypercholesterolemic Wistar Rats. International Journal of Nutrition and Food Sciences, 3(4), 355-360.

Aye, P., Adegun, M. (2013). Chemical Composition and some functional properties of Moringa, Leucaena and Gliricidia leaf meals. Agriculture and Biology Journal of North America, 4(1), 71-77.

Bais, S., Singh, G. S., Sharma, R. (2014). Antiobesity and Hypolipidemic Activity of Moringa oleifera Leaves against High Fat Diet-Induced Obesity in Rats. Advances in Biology, (ID 162914,), 1-9.

Buraimoh, A. A. (2011). Hepatoprotective effect of ethanolic leave extract of Moringa oleifera on the histology of paracetamol induced liver damage in wistar rats. Int. $J$. Anim. Vet. Adv., 3, 10-13.

Busani, M., Patrick, J. M., Arnold, H., Voster, M. (2011). Nutritional characterization of Moringa (Moringa oleifera Lam.) leaves. African Journal of Biotechnology, 10(60), 12925-12933.

El-awady, M. A. M., Hassan, M., Saleh, E., Gaber, A. (2016). Comparison of the antioxidant activities, phenolic and flavonoids contents of the leaves-crud extracts of Moringa peregrine and Moringa oleifera. International Journal of Biosciences (IJB), 8(1), 55-62.

El-Karamany, A. (2015). Effect of Irradiation on Rheological and Baking Propertes of Flour Wheat Grain . Journal of Food and Dairy Sciences, 6(12), 753-769.

Etab, S.Al.and Mona, S. H. (2017). Influence of Moringa oleifera Leaves on Antioxidant and Lipid Biochemical Markers in Male Albino Rats. Middle East Journal of Applied Science, 7(4), 651-662.

Fossati, P. , P. L. (1982). Determination of blood triglycerides using an oxidation system 28 . Clin. Chem., 28, 2077.

Frawley, B. (2009). Phytochemicals in plantbased foods could help battleobesity, diseases. Health Research.

Gatade, A. A., Ranveer, R. C., Sahoo, A. K. (2013). Nutritional analysis, total phenolic content, free radical scavenging activity and phytochemical analysis of leaves powder of Moringa oleifera (drumstick) and Cicer arietinum (Chick PEA). International Journal of Pharma and Bio Sciences, 4(3), 922-933.

Ghasi, S., Nwobod, E., Ofili, J. O. (2000). Hypocholesterolemic effects of crude extract of leaf of Moringa oleifera Lam in high-fat diet fed wistar rats. Journal of Ethnopharmacology, 69(1), 21-25.

Gheith, I., El-Mahmoudy, A. (2019). Amelioration of hyperlipidemia and atherosclerosis risk index by Moringa oleifera leaf extract. Life Science Journal, 16(2), 10-17.

Gray, A. M., Abdel-Wahab, Y. H., Flatt, P. R. (2000). No The traditional plant treatment, Sabucus nigra (Elder) exhibits insulin like and insulin releasing actions in vitro. Journal of Nutrition, 130, 15-20.

Hanson, P. M., Yang, R. Y., Tsou, S. C. S., Ledesma, D., Engle, L., Lee, T. C. (2006). Diversity in eggplant (Solanum melongena) for superoxide scavenging activity, total phenolics, and ascorbic acid. Journal of 
Food Composition and Analysis, 19(6-7), 594-600.

Jain, P. G., Patil, S. D., Haswani, N. G., Girase, M. V., Surana, S. J. (2010). Atividade hipolipidemica de Moringa oleifera Lam., Moringaceae, na hiperlipidemia induzida por dieta rica em gordura em ratos albinos. Brazilian Journal of Pharmacognosy, 20(6), 969-973.

Joshi, P., Mehta, D. (2010). Effect of dehydration on the nutritive value of drumstick leaves. Journal of Metabolomics and Systems Biology, 1(1), 5-9.

Leone, A., Spada, A., Battezzati, A., Schiraldi, A., Aristil, J., Bertoli, S. (2015). Cultivation, genetic, ethnopharmacology, phytochemistry and pharmacology of Moringa oleifera leaves: An overview. International Journal of Molecular Sciences, 16(6), 12791-12835.

Lesten, E. C. C., Emmanuel, C. M. (2018). Proximate, physical and chemical composition of leaves and seeds of Moringa (Moringa oleifera) from Central Malawi: A potential for increasing animal food supply in the 21st century. African Journal of Agricultural Research, 13(51), 2872-2880.

Lopez-Virella, M. F. (1977). Determination of blood triglycerides using an oxidation peroxidase system. Clin.Chem., 21.882

Ma, Z. F., Ahmad, J., Zhang, H., Khan, I., Muhammad, S. (2018). Evaluation of phytochemical and medicinal properties of Moringa (Moringa oleifera) as a potential functional food. South African Journal of Botany, 129, 40-46.

Mittall, M., MittalI, P., Agarwal, A. C. (2007). Pharmacognostical and phytochemical investigation of antidiabetic activity of Moringa oleifera lam leaf. The Indian Pharmacist, 6(59), 70-72.

Mouminah, H. H. S. (2015). Effect of dried Moringa oleifera leaves on the nutritional and organoleptic characteristics of cookies. Alexandria Science Exchange Journal, 36(4), 297-302.

Mulyaningsih, Lt. R., Yusuf, S. (2018).
Determination of Minerals Content in Leaves of Moringa Oleifera By Neutron Activation Analysis. GANENDRA Majalah IPTEK Nuklir, 21(1), 11.

Mune, M. A. M., Nyobe, E. C., Bassogog, C. B., Minka, S. R. (2016). A comparison on the nutritional quality of proteins from Moringa oleifera leaves and seeds. Cogent Food \& Agriculture, 2(1), 1-8.

Muniz, L. B., Alves-Santos, A. M., Camargo, F., Martins, D. B., Celes, M. R. N., \& Naves, M. M. V. (2019). High-lard and highcholesterol diet, but not high-lard diet, leads to metabolic disorders in a modified dyslipidemia model. Arquivos Brasileiros de Cardiologia, 113, 896-902.

Ndong, M., Uehara, M., Katsumata, S., Suzuki, K., T. (2007). Effects of oral administration of Moringa oleifera Lam on glucose tolerance in Goto-Kakizaki and wistar rats. Journal of Clinical Biochemistry and Nutrition, 40(3), 229-233.

Nilanjan Das , Kunal Sikder, Santinath Ghosh, Bernard Fromenty, S. D. (2012). Moringa oleifera Lam. leaf extract prevents early liver injury and restores antioxidant status in mice fed with high-fat diet. Indian Journal of Experimental Biology, 50(6), 404-412.

Paikra, B. K., Dhongade, H. K. J., Gidwani, B. (2017). Phytochemistry and pharmacology of Moringa oleifera Lam. Journal of Pharmacopuncture, 20(3), 194-200.

Pakade, V., Cukrowska, E., Chimuka, L. (2013). Comparison of antioxidant activity of Moringa oleifera and selected vegetables in South Africa. South Africa Journal of Science, 109, 1-5.

Pandu, S. M., Cherupanalli, R., Muthukumar, S. P. (2018). Effects of bound phenolic from defatted Moringa oleifera seed flour on dietinduced hypercholesterolemic mice. Journal of Food Biochemistry, 42(5), 1-9.

Pelin D., Incilay G. (2020). Determination of the Rheological Properties of Red and White Bread Wheat Flours with Different Methods.Doi:10.20944/Preprints202001.0 172.V1, 3(1), 30-52. 
Rajanandh, M.G., Satishkumar, M.N., Elango, K. and Suresh, B. (2012). Moringa Oleifera Lam. A herbal medicine for hyperlipidemia: A preclinical report. Asian Pa. J. Trop. Dis., 2, s790-s795.

Rajput, H., Prasad, S. G. M., Srivastav, P., Singh, N., Suraj, L., Chandra, R. (2017). Chemical and Phytochemical Properties of Fresh and Dried Moringa Oliferiea ( PKM1 ) Leaf Powder. Chemical Science Review and Letters, 6(22), 1004-1009.

Rakszegi, M., Balazs, G., Bekes, F. Harasztos, A., Kovacs, A., Lang, L., Bedo, Z. and T., S. (2014). Modelling water absorption of wheat flour by taking into consideration of the soluble protein and arabinoxylan components. Cereal Research Communications, 42(4), 629-639.

Rana, J. ., Nieuwdorp, M., Jukema, J. ., Kastelein, J. J. (2007). Cardiovascular metabolic syndrome-an interplay of, obesity, inflammation, diabetes and coronary heart disease. Diabetes Obes. Metab, 9, 218-223.

Rania, E. El-Gammal; Gehan, A. Ghoneim and Sh. M. ElShehawy. (2016). Effect of Moringa Leaves Powder (Moringa oleifera) on Some Chemical and Physical Properties of Pan Bread. J. Food and Dairy Sci., Mansoura Univ., 7(7), 307-314.

Saba, N. . (1993). Cooking ,Science and Art . Household College, Helwan Univ. 4th Edition-Darel-Maarif, Cairo.

Salamatullah,Q.; Hidehiko, Y., Akira, Y. (1983). Effect of dietary fiber on hypercholesterolemia induced by dietary PCB or cholesterol in rats. Journal Nutrition, 113, 1109-1118.

Sarkar, M., Bhowmick, S., Hussain, J., Hasan, M., Hossain, S. (2017). Hot Water Extract of Moringa oleifera Leaves Protects Erythrocytes from Hemolysis and Major Organs from Oxidative Stress in vitro. Journal of Basic and Applied Research, 3(3), 120-126.

Shermer, G., Jones, K. C. (1967). Public Housing is the Tenants. Washington, DC:
National Association of Housing and Redevelopment Officials.

Shokry, A. M. (2017). Evaluate the Nutritional Composition of Moringa oleifera Leaves Powder in Siwa Oasis and its Effect on Processed Moringa Food Products Properties. Middle East Journal of Agriculture Research, 6(4), 1438-1446.

Shousha, W. G., Aboulthana, W. M., Salama, A. H., Saleh, M. H., Essawy, E. A. (2019). Evaluation of the biological activity of Moringa oleifera leaves extract after incorporating silver nanoparticles, in vitro study. Bulletin of the National Research Centre, 43(1), 1-13.

Sohaimy, S. A. El, Hamad, G. M., Mohamed, S. E., Amar, M. H., Al-Hindi, R. R. (2015). Biochemical and functional properties of Moringa oleifera leaves and their potential as a functional food. Global Advanced Research Journal of Agricultural Science, 4(4), 188-199.

Stohs, S. J., Hartman, M. J. (2015). Review of the Safety and Efficacy of Moringa oleifera. Phytotherapy Research, 29(6), 796-804.

Tomaino,A.;Cimino,F.;Zimbalatti,V.; Venuti,V.; Sulfaro A., D. P. S. (2005). Influence of heating on antioxidant activity and the chemical composition of some spice essential oils. Food Chemistry, 89(4), 549544.

Valdez-Solana, M. A., Mejía-García, V. Y., Téllez-Valencia, A., García-Arenas, G., Salas-Pacheco, J., Alba-Romero, J. J., Sierra-Campos, E. (2015). Nutritional content and elemental and phytochemical analyses of moringa oleifera grown in Mexico. Journal of Chemistry, 2015, 1-9.

Vagelas, I., Sugar, I. R., Potential Use of Olive Oil Mill Waste Water to Control Plant and Post Harvest Diseases, Carpathian Journal of Food Science and Technology, Volume: 12, Baia Mare, 2020, pg. 140-144

Vergara-Jimenez, M., Almatrafi, M. M., Fernandez, M. L. (2017). Bioactive components in Moringa oleifera leaves protect against chronic disease. 
Antioxidants, 6(4), 1-13.

Zhanga, W., Zhangb, J., Jianga, Q., Xia, W. (2013). The hypolipidemic activity of chitosan nanopowder prepared by ultrafine milling. Carbohydrate Polymers, 95(1), 487-491.

Zoliner, N., Kirsch, K. (1962). Microdetermintion of lipids by the sulfophospho vanillin reaction. Z.fur die Gesampte Exp Med, 135, 545

\section{Acknowledgment}

The authors sincerely acknowledge their gratitude to the efforts of Pathology Department, Faculty of Veterinary Medicine of Cairo University and National organization for drug control and research (NODCAR) 